\title{
Androgens and androgen receptor signaling in prostate tumorigenesis
}

\author{
Ye Zhou, Eric C Bolton' and Jeremy O Jones
}

Department of Molecular Pharmacology, Beckman Research Institute, City of Hope National Medical Center, 1500 E Duarte Road, Beckman 2310, Duarte, California 91010, USA

1 Department of Molecular and Integrative Physiology, University of Illinois at Urbana-Champaign, Urbana, Illinois 61801, USA

Correspondence

should be addressed

to $J$ O Jones

Email

jjones@coh.org

\begin{abstract}
Androgens and androgen receptor (AR) signaling are necessary for prostate development and homeostasis. AR signaling also drives the growth of nearly all prostate cancer cells. The role of androgens and AR signaling has been well characterized in metastatic prostate cancer, where it has been shown that prostate cancer cells are exquisitely adept at maintaining functional AR signaling to drive cancer growth. As androgens and AR signaling are so intimately involved in prostate development and the proliferation of advanced prostate cancer, it stands to reason that androgens and AR are also involved in prostate cancer initiation and the early stages of cancer growth, yet little is known of this process. In this review, we summarize the current state of knowledge concerning the role of androgens and AR signaling in prostate tissue, from development to metastatic, castration-resistant prostate cancer, and use that information to suggest potential roles for androgens and AR in prostate cancer initiation.
\end{abstract}
Key Words
- androgen
- prostate
- prostate cancer
- androgen receptor
- cancer initiation

\section{Introduction}

Prostate cancer is the second most frequently diagnosed cancer and the sixth leading cause of cancer death in men worldwide (Siegel et al. 2013). Prostate cancer can often be cured with definitive local intervention (surgery or radiation), but once the cancer metastasizes, it is incurable. Our most effective regimens for treating metastatic prostate cancer have arisen from the pioneering experiments, in which suppression of testicular testosterone production was shown to cause tumor regression (Huggins \& Clark 1940). Since then, our ability to inhibit androgen synthesis and androgen receptor (AR) signaling has improved, and several agents are now approved for treatment of metastatic prostate cancer (Friedlander \& Ryan 2012). The observations that prostate development depends on androgens and AR signaling and that nearly all prostate cancer cells are critically dependent upon androgens and AR signaling for growth are the basis for the hypothesis that androgens and
AR signaling play a causative role in prostate tumorigenesis; however, little is known about this process. One early event that appears to occur in all prostate cancers is a transition from AR-guiding cytodifferentiation of luminal epithelial cells to AR driving the uncontrolled proliferation of these cells. This 'malignancy switch' is likely a central event in tumorigenesis, as AR becomes the primary driver of neoplastic growth in malignant cells. In this review, we will briefly discuss the known roles of androgens and AR in prostate development and homeostasis and in advanced stages of prostate cancer, focusing on aspects of these processes that might inform the role of androgens and AR in prostate cancer initiation. We will conclude with what is known concerning the role of androgens and $\mathrm{AR}$ in prostate cancer initiation and the early stages of cancer growth, and discuss possible mechanisms by which androgens and AR contribute to tumorigenesis.

Published by Bioscientifica Ltd 


\section{Androgens and AR in prostate development and homeostasis}

The prostate is a primary target organ of androgens, and the androgenic dependence of prostate development and homeostasis has been well reviewed (Litvinov et al. 2003, Marker et al. 2003). Briefly, the androgens testosterone, produced by the fetal testis, and dihydrotestosterone (DHT), produced by local conversion of circulating testosterone by $5 \alpha$-reductase, act to specify the development of the urogenital sinus (UGS) into prostate via stimulation of the AR (Fig. 1A) (Pointis et al. 1979, 1980). The adult prostate consists of a fibromuscular stroma comprised of various mesenchymal lineage cells surrounding secretory ducts comprised of basal and luminal epithelial cells, with rare neuroendocrine cells interspersed. The postnatal development and maturation of the prostate are believed to depend on the reciprocal interactions between the stromal (mesenchymal) and epithelial compartment (Fig. 2A) (Hayward et al. 1998). The stromal cells are thought to secrete peptide growth factors (andromedins) in response to androgen signaling through AR in these cells, although a true andromedin remains to be identified (Lu et al. 1999, Planz et al. 1999). Binding of andromedins to the receptors on basal cells promotes their proliferation and differentiation into luminal cells (Wikstrom et al. 1999) and generates intracellular signals, which repress the apoptosis pathway to allow homeostatic maintenance of luminal cells. The canonical pathway of prostate epithelial differentiation suggests that basal cells can self-renew or differentiate into luminal cells in a multistep process that involves partially differentiated intermediate, or transit amplifying cells (Wang et al. 2001). However, there is still much to learn about the process of prostate epithelial differentiation and self-renewal, as recent work has clearly demonstrated the existence of self-renewal for both luminal and basal cell populations (Choi et al. 2012), and unraveling the process of differentiation has important implications for cancer initiation (Wang \& Shen 2011).

One unanswered question in prostate cancer initiation concerns the role of AR in the different cells of the prostate. Luminal cells express high levels of $\mathrm{AR}$ and respond directly to androgens by stimulating production and secretion of prostatic differentiation markers. Basal cells are usually considered to lack AR expression, but several studies have reported AR localization using immunohistochemistry in a subset of basal cells in normal human and rodent prostate specimens as well as hyperplastic human prostate samples (Bonkhoff \& Remberger 1993,
Mirosevich et al. 1999). Similarly, intermediate cells are considered to lack AR expression. However, increasing evidence shows that some intermediate cells can express $\mathrm{AR}$, including experiments in ARKO mice that demonstrated that AR expression in intermediate cells is necessary for suppressing proliferation and promoting differentiation into luminal epithelial cells (Mirosevich et al. 1999, Lee et al. 2012). The disposition of the androgen/AR signaling axis in these cells likely influences future prostate cancer development.

Homeostatic maintenance of adult prostate epithelium is also dependent on AR signaling. Androgen deprivation by castration in adult mice results in prostate involution due to epithelial cell apoptosis (Isaacs 1984, Kyprianou \& Isaacs 1988), and androgen supplementation in castrated animals can restore prostate size and ductal morphology (Sugimura et al. 1986, Kyprianou \& Isaacs 1988). In a series of pioneering experiments, epithelial cells from WT or AR-null mice were combined with normal rat stroma and engrafted into immunocompromised mice where they formed tissue resembling prostate (Kurita et al. 2001). After castration of host mice, apoptosis was observed in both WT and AR-null recombinant prostates, and androgen supplementation blocked castration-induced apoptosis in both recombinant tissues. These and other experiments suggest that stromal AR signaling promotes epithelial cell growth and prostate regeneration while epithelial AR functions to maintain homeostasis through suppression of basal cell proliferation and stimulation of differentiated luminal cell survival (Wu et al. 2007, Yu et al. 2012). These studies establish a framework for androgen and AR action in the various cell types that have been implicated in homeostatic regulation of the adult prostate gland, and they provide a benchmark against which to measure changes that occur in the androgen/AR signaling axis during the development of prostate cancer.

\section{Androgens and AR in metastatic castration-resistant prostate cancer}

Luminal epithelial AR plays a suppressive role during adult prostate homeostasis, but it plays a very different role in cancerous prostate tissue, which is composed primarily of luminal epithelial cells (Fig. 1B and C). The role of androgens and AR has been intensely studied in metastatic prostate cancer and much of what has been discovered in this setting may provide clues to the role of androgens and AR in the early stages of tumorigenesis, of which comparatively little is known. Androgen deprivation

Published by Bioscientifica Ltd. 
A Normal prostate

Normal luminal cell
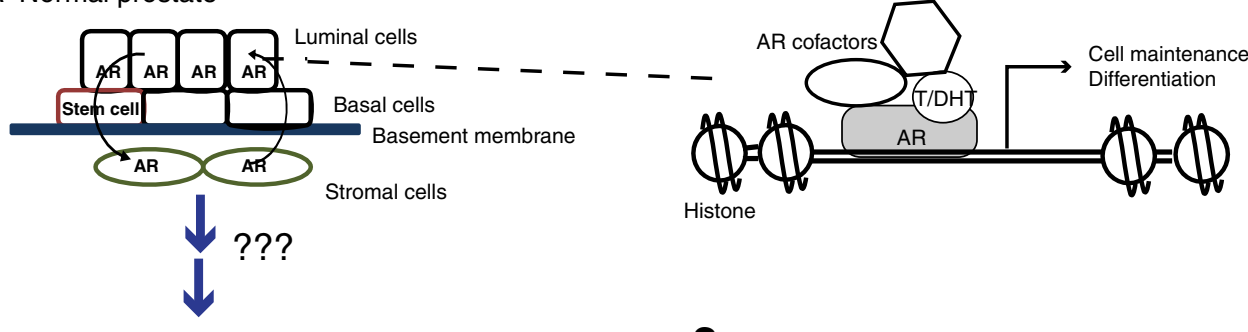

B Prostatic intraepithelial neoplasia<smiles>[Te]</smiles>

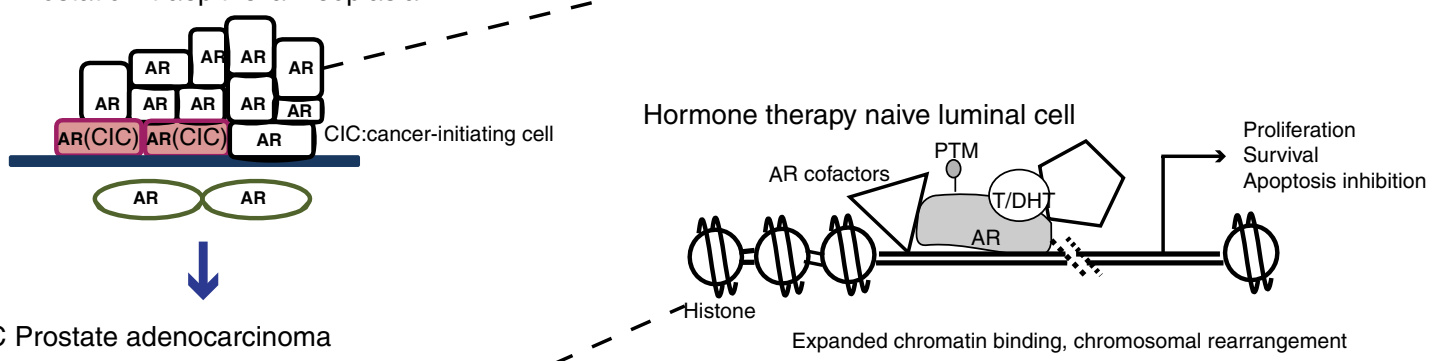

C Prostate adenocarcinoma

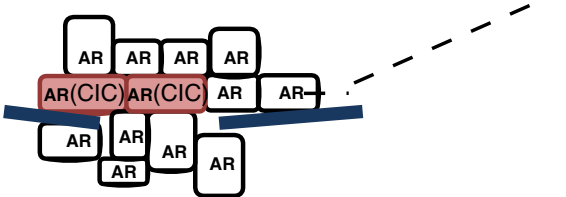

Castration-resistant luminal cell
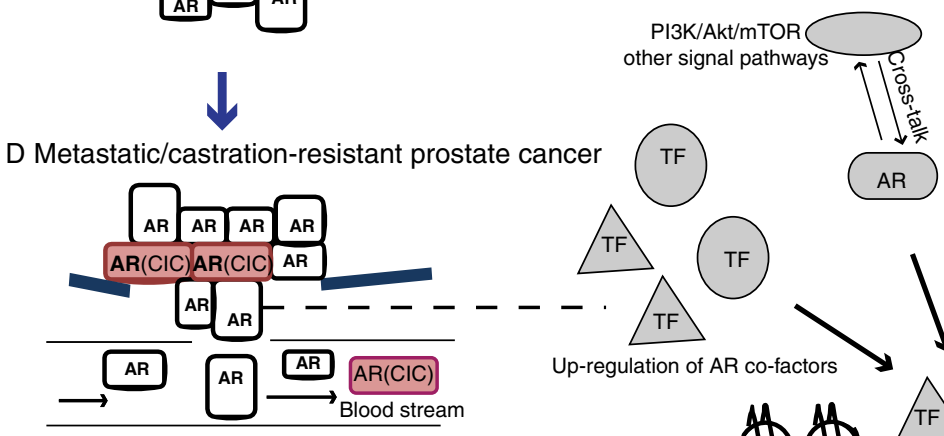

Up-regulation of genes in androgen biosynthesis
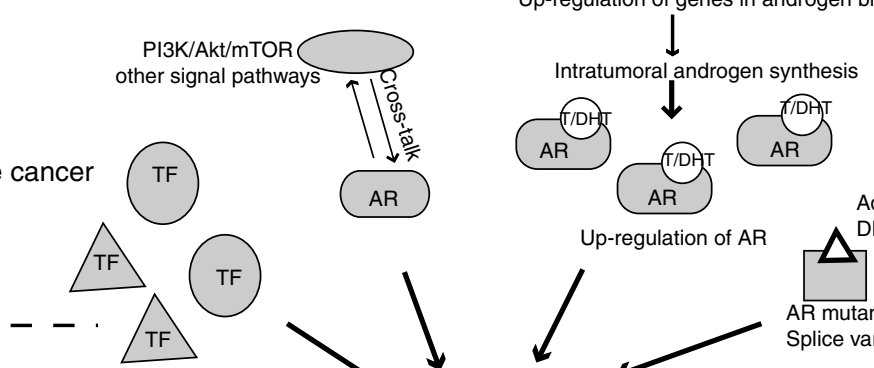

Up-regulation of AR co-factors
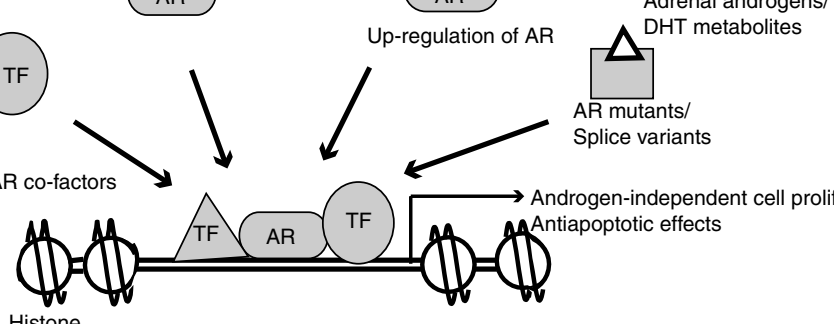

Histone

\section{Figure 1}

The role of AR signaling in prostate development and cancer: $(A)$ in normal prostate, prostate homeostasis is well balanced by reciprocal signaling between prostate stromal and epithelial layers. Prostate stem cells are rare and maintained at a low self-renewal rate. In normal luminal epithelial cells, AR translocates to the nucleus upon androgen binding where it interacts with cofactors and transcriptional machinery to direct the transcription of genes involved in cell differentiation to maintain prostate homeostasis. Basal epithelial cells express very little AR or none at all. (B) Through unknown mechanisms, normal prostate cells are transformed and become cancer initiating cells (CICs). Prostatic intraepithelial neoplasias or other early cancer lesions become histologically evident. Associated with this event, cells in the basal layer express higher levels of $A R$, but the status of $A R$ in these earliest cancer cells is unknown.

therapy (ADT) remains the most effective therapy for metastatic prostate cancer. However, androgen depletion is usually associated with the recurrence of prostate cancer. This recurrent disease is termed as castration-resistant
(C) In prostate adenocarcinoma, a series of cellular and molecular changes occur, which result in luminal cells in which the AR transcriptional program switches from regulating cell differentiation to cell proliferation. Altered AR activity is likely influenced by altered post-translational modifications (PTMs), altered association with coregulators and other transcription factors, and genomic rearrangements. (D) In CRPC, as the availability of androgen from the bloodstream becomes limited, prostate cancer cells can maintain AR activity through other mechanisms (which include upregulation of AR and its splice variants, intratumoral androgen synthesis, cross-talk with other signal pathways, and increased/altered expression of AR cofactors). A full colour version of this figure is available via http://dx. doi.org/10.1530/JME-14-0203.

prostate cancer (CRPC). An interesting feature of CRPC is that, despite low levels of systemic androgen after castration, active AR signaling is maintained in these recurrent prostate cancers (Mostaghel \& Plymate 2011).

Published by Bioscientifica Ltd. 
A Paracrine pathway: prostate homeostasis

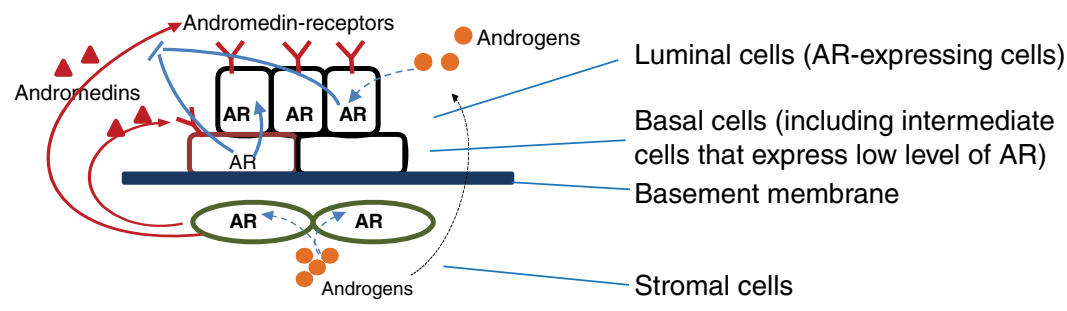

B Autocrine pathway: AR malignancy switch

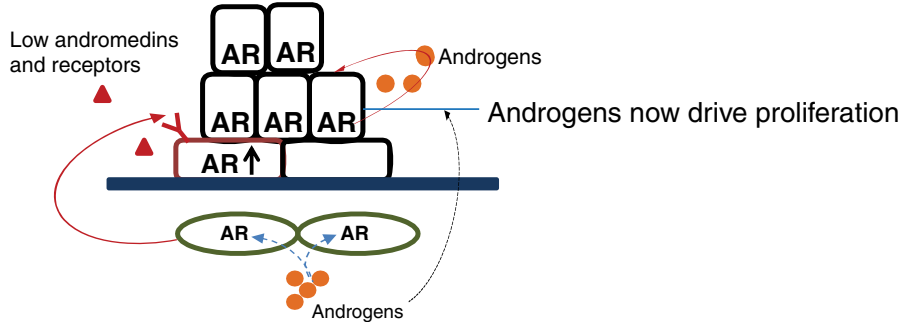

\section{Figure 2}

Paracrine-to-autocrine AR signaling and the AR malignancy switch: (A) in normal adult prostate, androgens regulate growth and maintenance of the prostate epithelium through a paracrine mechanism. In the presence of adequate androgens, andromedins are produced by stromal cells and bind to specific receptors on prostate epithelial cells, which promote the proliferation and survival of prostate epithelial cells. AR signaling in the epithelial cells counteracts these signals and promotes differentiation into luminal cells. (B) During malignant transformation, the paracrine mechanism of AR action is replaced by an emergent autocrine mechanism.
The AR-mediated proliferation and survival of a subset of epithelial cells become cell-autonomous, and these cells are no longer dependent on stromal paracrine signals (i.e. andromedins). The cell-autonomous AR signaling pathologically allows androgen/AR complexes to bind and enhance expression of survival and proliferation genes that are normally not regulated by these complexes in either intermediate cells or luminal cells. A full colour version of this figure is available via http://dx.doi.org/ 10.1530/JME-14-0203.

AR-Vs, and AR coregulators, many other signaling pathways have been shown to influence the AR signaling axis and the development of CRPC (for review, see Lamont \& Tindall (2011)). Notably, the PI3K/Akt/mTOR pathway and AR signaling pathway have recently been shown to regulate each other through complex reciprocal feedback mechanisms (Carver et al. 2011, Mulholland et al. 2011). Other studies further suggest that PI3K signaling allows continued AR signaling despite reduced androgen levels, possibly through activation by post-translational modification (PTM) or reduced corepressor activity (Mulholland et al. 2006).

The other prevailing explanation for persistent AR signaling in the setting of castrate serum testosterone concentrations is the continued presence of intracellular androgens at levels adequate to activate WT AR. Several research groups have shown that substantial amounts of testosterone and DHT are present in human prostate tissue after pharmacological or surgical castration (Cai \& Balk 2011). The levels of these intraprostatic androgens are sufficient to activate the AR and stimulate the expression of AR-regulated genes. The source of these intraprostatic

Published by Bioscientifica Ltd. http://jme.endocrinology-journals.org DOI: 10.1530/JME-14-0203
(C) 2015 Society for Endocrinology Printed in Great Britain 
androgens is not yet clear, but changes in the amount of mRNA and in the expression rate of enzymes in the steroid synthesis pathway have been confirmed in different studies (Cai \& Balk 2011), which suggests that CRPC cells have the ability to synthesize androgens de novo from available precursors to maintain functional levels of androgens and AR signaling.

Although the above changes in the androgen/AR signaling axis occur in metastatic CRPC under selective pressure from hormonal therapies, it is possible that they are relevant in the earliest stages of prostate cancer as well, especially in aging men with decreasing systemic testosterone levels. Accumulating evidence suggests that benign prostate tissue can adapt to low systemic testosterone in many of the same ways CRPC tissue does, as will be discussed in the following sections.

\section{AR in prostate cancer initiation}

Direct evidence for the necessity of AR in prostate cancer initiation is sparse. One suggestion that AR plays a causative role in tumorigenesis comes from studies demonstrating an association between CAG repeat length, which influences AR activity, and the risk of prostate cancer (PC); however, other studies contradict these findings (Bosland 2000, Nelson et al. 2003, Lindstrom et al. 2010, Price et al. 2010). Two studies of genetically modified mice suggest that AR plays a role in cancer initiation. $45 \%$ of mice with AR overexpression driven by the probasin promoter developed dysplastic lesions or prostatic intraepithelial neoplasia (PIN), but no cancer was observed (Stanbrough et al. 2001). However, mice expressing a constitutively active E231G AR mutant developed adenocarcinoma in the ventral prostate and metastases (Han et al. 2005). More recently, a gene signature set derived from this model was able to distinguish between primary Gleason grade 3 and Gleason grade 4 tumors and between human nonmalignant and cancerous prostate (Thompson et al. 2012).

Although not directly testing the contribution of AR to tumor initiation, several clinical trials in men with localized prostate cancer have shown that competitive antagonists of AR can reduce tumor volume and the risk of progression, suggesting that AR does play a role in the early stages of the disease. For example, bicalutamide monotherapy significantly improves progression-free survival and reduced the risk of objective progression in several large, prospective studies (McLeod et al. 2006, Wirth et al. 2007). Several studies employing intermittent ADT comprised of bicalutamide, luteinizing hormonereleasing hormone (LHRH) agonists, and $5 \alpha$-reductase inhibitors in men with localized prostate cancer have shown benefits as well, including a study of 110 men where a low serum prostate-specific antigen (PSA) level was maintained by $92 \%$ of men over a median of 55 months follow-up (Leibowitz \& Tucker 2001, Scholz et al. 2011). Studies of competitive antagonists in men without history of prostate cancer have been difficult to carry out, so we may not be able to directly determine the effect of AR inhibitors on human prostate cancer incidence.

Perhaps the key molecular event involving AR in prostate tumorigenesis is the transition from AR guiding differentiation to driving proliferation in luminal epithelial cells (Fig. 2A and B). The specifics of this 'malignancy switch' have been poorly described, and even less is known about what drives this switch. As discussed in the first section, AR action in stromal cells drives the formation of the prostate, but AR action in luminal epithelial cells controls cytodifferentiation and prostatic secretions. During the initiation of prostate cancer, distinct changes occur in AR signaling pathways (Fig. 2B). Intermediate cells express higher levels of AR, which results in AR stimulating the proliferation of these cells instead of their differentiation. The proliferation and the survival of a subset of dysplastic prostate epithelial cells are no longer solely dependent on stromal paracrine signals (i.e. andromedins); instead, cell-autonomous AR signaling becomes active (Gao \& Isaacs 1998, Gao et al. 2001, Memarzadeh et al. 2011). The cell-autonomous AR signaling pathologically allows androgen/AR complexes to bind to and enhance expression of survival and proliferation genes that are normally not regulated by these complexes in either intermediate cells or luminal cells (Gao \& Isaacs 1998, Gao et al. 2001, Memarzadeh et al. 2011). Using DNA microarray or other high-throughput approaches, several studies have comparatively analyzed the expression profile of androgen-regulated genes in model cell lines and in clinical specimens derived from prostate cancer patients at different developmental stages or with varying treatment histories (see review Jin et al. (2013)). For instance, Nelson et al. (2002) characterized the temporal program of transcription, which reflects cellular responses to androgens in neoplastic prostate epithelium, and identified 146 androgen-responsive genes with transcript alterations; some of these transcripts encode proteins involved in metabolism, cell proliferation, and prostate differentiation. Similar results have been reported in cells derived from CWR22-relapsed tumors (Chen et al. 2010). These studies suggest that changes in the AR-driven transcriptional program are fundamental to prostate cancer development and progression, but they offer little

Published by Bioscientifica Ltd. 
insight into the role of AR transcriptional activity in human benign luminal epithelial cells. Several genome-wide studies in mice have shed some light on the AR-regulated program in benign prostate tissue. Wang et al. (2007) profiled gene expression by microarray in the mouse after castration and hormone replacement, finding that most significantly regulated genes were involved in cell adhesion, metabolism, and cell-cycle progression. Pritchard et al. (2009) profiled gene expression in the mouse prostate at seven time points, from prostate induction through branching morphogenesis, to full adult secretory differentiation. Comparing their findings with earlier gene expression studies in two genetically engineered mouse models of prostate cancer (Pten-/- and Myc overexpression), they found that genes altered in murine prostate adenocarcinoma were consistent with expression changes during the branching morphogenesis stage of prostate development. Schaeffer et al. (2008) performed a similar experiment, characterizing the temporal program of transcription in response to DHT in embryonic mice. They found several pathways important for prostate bud development, including FGF, PTEN/PI3K/mTOR, and Wnt signaling. Interestingly, by comparison with several human prostate cancer microarray datasets (Tomlins et al. 2007a), the developmental genes had significant overlap with genes known to be involved in early stages of cancer development and in invasion of advanced prostate cancers. Equivalent experiments in humans cannot be performed, but a few studies have attempted to determine the expression of known AR target genes in benign prostatic epithelia in comparison with early-stage malignant epithelia. In one study, Velasco et al. (2004) demonstrated that FKBP51 expression was significantly higher in prostate tumor samples compared with benign prostatic hyperplasia (BPH) samples and may be a potential diagnostic marker for prostate cancer. Together, these studies of the AR transcriptome provide reference gene sets for normal and cancerous prostate epithelial cells, which can serve as a marker for the AR malignancy switch.

Our knowledge of the gene regulatory programs driven by AR in benign vs early prostate cancer luminal cells is deficient and must be expanded. Likewise, our knowledge of AR chromatin binding patterns in benign vs cancerous luminal cells is limited. Using ChIP-on-Chip and ChIP-Seq, multiple groups have reported thousands of AR direct binding events in prostate cancer cell lines and tissues, showing different binding patterns in different stages of cancer (Massie et al. 2011, Jin et al. 2013, Sharma et al. 2013). Because all of these studies have been performed in cancerous cells, little is known of AR binding patterns in benign prostate or very-early-stage prostate cancers. At the most recent ASCO meeting, Pomerantz et al. (2014) have reported on AR ChIP-seq experiments in normal and cancerous human prostate samples. DNA binding motif analysis showed that the consensus AR-binding site is the most significantly enriched motif in normal tissue, while FOXA1, HOXB13, and AR-binding sites were most significantly enriched in tumor tissue. This suggests that AR chromatin binding becomes more promiscuous, perhaps aided by altered association with the FOXA1 and HOXB13 transcription factors. Importantly, this study provides a potential read-out for the AR malignancy switch. While other factors may play a role, the altered binding preference of AR can likely be used as an indicator of the AR malignancy switch in many prostate cancers. However, the AR cistrome and transcriptome must still be more thoroughly characterized in benign and early cancerous luminal cells. Once a better description of the AR malignancy switch exists, it will then be possible to investigate factors that regulate the switch.

Several factors have already been proposed to drive altered AR binding behavior, including overexpression of AR and changes in AR or its binding partners (e.g. PTMs) that alter AR association with cofactors, other transcription factors, and chromatin. Direct changes to AR, including overexpression and PTMs that alter its association with DNA could contribute to the malignancy switch. In CRPC cells, Urbanucci et al. (2012) found that the overexpression of AR sensitizes the receptor to associate with chromatin, which can increase the number of binding sites that are occupied. These new binding events enable AR to increase the expression of cell cycle genes, and therefore, to drive cell proliferation in CRPC (Wang et al. 2009a). Increased expression of AR during initiation of prostate cancer might also drive a change in chromatin binding patterns that facilitate malignant proliferation. In recent years, a number of PTMs that alter AR activity have been discovered, including phosphorylation, acetylation, SUMOylation, methylation, and ubiquitination (Coffey \& Robson 2012, Gioeli \& Paschal 2012). Some PTMs have been implicated in malignant transformation. For instance, AR serine-81 phosphorylation is increased in prostate cancer and leads to increased AR expression in prostate cancer cells. Phosphorylation of serine-81 also regulates AR chromatin binding and permits the recruitment of coactivators and subsequent chromatin remodeling required for transcription activity (Chen et al. 2012), which could attribute to the AR malignancy switch.

AR obviously plays a central role in the AR malignancy switch, but other factors likely influence the process.

Published by Bioscientifica Ltd. 
The altered interaction of AR with different AR cofactors can affect how and where AR binds to DNA and might provide clues to how the AR malignancy switch is initiated. The binding activity of AR and thus the specificity of its transcriptional regulation are tightly controlled by a collection of pioneer factors and transcriptional cofactors. Over a hundred proteins have been found to interact with $\mathrm{AR}$ and effect AR recruitment to DNA and AR-regulated transcription (reviewed in Mills (2014)). Notably, a possible sequence of molecular events associated with dynamic AR reprograming during clinical prostate cancer progression has been suggested (Mills 2014). This model proposes that DNA damage and chromatin rearrangement, caused by oxidative damage and other factors, leads to aberrant expression of AR coregulators, such as ETS family members, and subsequently causes changes in the AR-regulated transcriptome, which disrupts cellular balance and leads to AR-driven luminal cell proliferation. Among the AR coregulators that are candidates to drive the AR malignancy switch, the ETS family stands out. Chromosomal fusions of androgen responsive promoters, primarily TMPRSS2, with ETS family genes, primarily $E R G$, have been found in a large percentage of prostate cancer patients and are thought to occur early in cancer development (Demichelis \& Rubin 2007, Kumar-Sinha et al. 2008, Weischenfeldt et al. 2013). ERG protein physically interacts with AR, but attenuates AR transcriptional activity at gene-specific loci, acting as an AR corepressor ( $\mathrm{Yu}$ et al. 2010). However, ERG can perturb cell differentiation through interactions with polycomb group proteins ( $\mathrm{Yu}$ et al. 2010). Another ETS family member often found in gene fusions, ETV1, upregulates AR-regulated genes as well as genes that are involved in steroid biosynthesis and metabolism (Baena et al. 2013). Although transgenic mouse models have revealed that overexpression of ETS family members in the prostate does not give rise to adenocarcinomas, pre-cancerous lesions including PIN have been reported in these models (Tomlins et al. 2007b, Klezovitch et al. 2008, Carver et al. 2009, King et al. 2009, Shin et al. 2009). It will be essential to determine if the AR malignancy switch is activated in these lesions.

Although oncogenic ETS gene fusions may play a central role in the AR malignant switch, these chromosomal rearrangements are thought to occur in $27-79 \%$ of patients (Williams et al. 2010), therefore additional factors likely contribute to the switch. Other candidates include $c-M Y C$ and EZH2. Amplification of the $c-M Y C$ oncogene has been shown to occur in PIN lesions as well as later stages of prostate cancer development (Ribeiro et al. 2007,
Shen \& Abate-Shen 2010). Although in prostate cancer there is no genome-wide characterization of the interplay between $A R$ and $c-M Y C, c-M Y C$ physically interacts with AR (Gao et al. 2013) and $A R$ and $c-M Y C$ share some coregulators (see review Mills (2014)) including bromodomain-containing proteins, which bind to active chromatin via recognition of acetylated lysine on histones (Jang et al. 2005). It is possible that the combination of bromodomain-containing proteins, c-MYC and AR, can function to synergize recruitment of the transcriptional machinery, altering the AR-regulated cistrome and transcriptome. EZH2 is an epigenetic modifier that has been implicated in prostate carcinogenesis (Yang \& Yu 2013). Studies have shown that abnormalities in the epigenetic landscape in prostate cancer can be detected at the earliest stages of transformation, the most remarkable being DNA methylation (Yegnasubramanian et al. 2004). DNA methylation is an event with close links to EZH2 activity, as EZH2 can directly interact with several DNA methyltransferases (DNMT1, DNMT3A, and DNMT3B; Sauvageau \& Sauvageau 2010). An extensive list of genes, which exhibit hypermethylation in prostatic tumor cells, has been reported and includes genes involved in signal transduction, hormone response, cell cycle, and oxidative damage response ( $\mathrm{Li}$ et al. 2004). In addition to its capacity as an epigenetic modifier, EZH2 was recently reported to function as an AR coactivator, although its coactivator activity is dependent on AKT-mediated phosphorylation of EZH2 (Xu et al. 2012). Using ChIP-seq, EZH2 was found to bind not only to its consensus sites, but also to canonical AR binding sites (Zhao et al. 2012). It is possible that the coordinate regulation of $\mathrm{AR}$ chromatin binding and transcriptional regulation by AKT, EZH2, and DNA methylation cause AR to drive cell proliferation and/or suppress genes associated with prostatic differentiation (Zhao et al. 2012), thus contributing to the AR malignancy switch.

Future studies are imperative to determine the contribution of each of the above-mentioned factors to the initiation of the AR malignancy switch during the transformation of benign luminal cells into cancerous cells. An increased understanding of the DNA binding events and subsequent gene regulatory programs that distinguish AR activity in benign and malignant luminal epithelial cells will facilitate such studies.

\section{Androgens in prostate cancer initiation}

AR likely plays a central role in tumorigenesis, and so too do its ligands. There is compelling evidence for androgens

Published by Bioscientifica Ltd. 
in the initiation of prostate cancer, both from clinical trials and animal studies. Many retrospective trials have been conducted to determine the correlation between serum androgen levels and prostate cancer risk. In a longitudinal study of $>200000$ European men, higher levels of circulating testosterone were found to be related with reduced risk of prostate cancer with the odds ratio for the top vs bottom quintile of $0.80(95 \% \mathrm{Cl}=0.59-1.06$; Stattin et al. 2004). Similar conclusions have been made through several other retrospective and prospective studies. Recently, two studies have clearly demonstrated a protective effect of increasing serum testosterone levels in hypogonadal men. In the first, registry studies of 942 men with serum testosterone levels $\leq 12.1 \mathrm{nmol} / 1$ from three German centers who received testosterone undecanoate for up to 16 years showed that men taking testosterone had a prostate cancer incidence of $<55 / 10000$ patient-years in all three centers compared with an incidence of 116/10 000 patient-years in the PLCO trial or 96.6/10 000 patient-years in the ERSPC trial (Haider et al. 2014). The second report prospectively evaluated prostate cancer prevalence in elderly hypogonadal subjects $(n=261)$ under long-term testosterone replacement therapy (TRT) compared with an agematched control group. They found that the TRT group had fewer, smaller tumors and less malignancy, and that lower levels of serum testosterone were associated with an increased risk of prostate cancer (Yassin et al. 2014). In addition, several cross-sectional studies have found that a low serum testosterone level at the time of prostate cancer diagnosis is associated with more aggressive disease (Massengill et al. 2003, Imamoto et al. 2005, Isom-Batz et al. 2005). Schatzl et al. (2001) found that not only did men with low serum testosterone have more aggressive cancer, but AR expression was also elevated in the prostates of these patients. Moreover, Morgentaler et al. (1996) have reported that decreased serum testosterone levels can be an indicator for occult prostate cancer. While there are conflicting studies on the relationship between serum testosterone and prostate cancer risk (Endogenous Hormones and Prostate Cancer Collaborative Group et al. 2008), the bulk of the more recent studies suggests a link between low serum testosterone and increased prostate cancer risk.

Further evidence that androgens are involved in tumorigenesis comes from clinical trials with androgen synthesis inhibitors in men with localized prostate cancer. Treatment with a variety of androgen synthesis inhibitors such as dutasteride ( $5 \alpha$-reductase inhibitor), abiraterone (CYP17A inhibitor), and lupron (LHRH agonist) can cause established tumors to regress (see review Hu et al. (2013)). Two large randomized prospective preventative trials have utilized the $5 \alpha$-reductase inhibitors dutasteride and finasteride and have shown a $23-24 \%$ reduced risk of developing prostate cancer in men using these drugs for 4-7 years (Andriole et al. 2004, Goodman et al. 2004). These drugs prevent local conversion of testosterone to DHT, thus lowering tissue androgen levels instead of systemic levels. One criticism has been that these agents might merely be slowing the growth of pre-existing small cancers, which likely contributes to the lower incidence of cancer by biopsy detection. However, it is very likely that reduced tumorigenesis also contributes to the lower incidence of detection.

Evidence for the involvement of androgens in prostate tumorigenesis also comes from genetic association studies that have revealed polymorphisms in androgen pathway genes that are associated with prostate cancer susceptibility. 17 $\beta$-hydroxysteroid dehydrogenase (HSD17B), cytochrome P-450c17 (CYP17), and steroid-5- $\alpha$-reductase type 2 (SRD5A2) all encode proteins involved in androgen biosynthesis, and the majority of studies, but not all, have found alleles of these genes that significantly increase the risk of developing prostate cancer (see reviews Nelson et al. (2003), Kraft et al. (2005), and Setiawan et al. (2007)). The 3-hydroxysteroid dehydrogenase (HSD3B) locus encodes two androgen metabolism enzymes that convert DHT into inactive metabolites in steroid target tissues. Linkage analysis suggests that this locus is associated with prostate cancer susceptibility (Xu et al. 2001). An additional study sequenced both HSD3B1 and HSD3B2 genes and identified 11 single-nucleotide polymorphisms (SNPs), four of which were associated with hereditary and sporadic prostate cancer susceptibility (Chang et al. 2002). CYP19A1 encodes an enzyme that catalyzes the conversion of androgens to estrogens. Recent studies have suggested that functional genetic polymorphisms in the CYP19A1 gene may modify serum and/or intratumoral sex hormone levels and therefore influence prostate cancer risk and survival (Latil et al. 2001, Suzuki et al. 2003, Tsuchiya et al. 2006, Kanda et al. 2015). The androgen transporter gene SLCO2B1 also has a polymorphism that has been associated with prostate cancer risk and outcome (Yang et al. 2011). While none of these associations are incredibly strong, taken together, these findings suggest androgen pathway genes likely influence prostate cancer risk, suggesting that androgens are involved in tumorigenesis.

Experiments in animal models suggest that long-term exposure to both high and low systemic androgens can increase the rate of prostate cancer development.

Published by Bioscientifica Ltd 
Administration of exogenous testosterone in combination with or without estrogen and chemical carcinogens has been used to induce prostate cancer in several rat strains, and has been well reviewed elsewhere (Bosland \& Mahmoud 2011). Less well appreciated are animal studies in which chronic exposure to low testosterone has increased the risk of cancer. Banach-Petrosky et al. (2007) used a genetically engineered mouse model (Nkx3.1; Pten mutant mouse) to study the relationship between androgen levels and prostate tumorigenesis and showed that prolonged exposure to low testosterone promoted a more aggressive phenotype of cancer and accelerated tumor progression compared with normal or castrate levels of testosterone. Another study showed that rats treated with methylnitrosourea and exposed chronically to low testosterone developed prostate cancer, which could be inhibited by the AR competitive antagonist flutamide (Bosland \& Mahmoud 2011). Our recent findings would suggest that both supra- and sub-physiological serum levels of testosterone place adaptive pressure on the rodent prostate to maintain consistent levels of androgens and AR signaling (Zhou et al. 2013), which may account for the increased rate of prostate cancer in either setting.

Additional studies in both humans and animals suggest a paradoxical relationship between prostate cancer risk and serum androgen levels. One possible explanation for the inverse relationship between serum androgen levels and prostate cancer risk is that serum androgen levels are a poor surrogate for prostatic androgen levels. It has been well recognized that prostate and prostate cancer tissues are only modestly influenced by serum levels of androgens. Reports of the molecular impact of TRT as well as of male hormonal contraception on intraprostatic androgen concentration and androgen action indicate that intraprostatic levels of androgens are not affected by testosterone supplementation (Page et al. 2006, Mostaghel et al. 2012). A small study in medically castrated healthy men revealed that despite a $94 \%$ decrease in serum testosterone, intraprostatic testosterone and DHT levels remained within $20-30 \%$ of control values, and prostate cell proliferation, apoptosis, and androgen-regulated protein expression were unaffected (Page et al. 2006). Our group has recently used a rat model to demonstrate that tissue levels of androgens in healthy rat prostate remain constant despite being chronically exposed to a wide range of serum testosterone (Zhou et al. 2013). We also found that androgen levels in the prostate of rats with prolonged exposure to low testosterone were sufficient to maintain active AR signaling. Together, these studies suggest that benign prostate tissue is able to maintain functional levels of tissue androgens despite low serum levels. Thus, benign tissue adapts to low serum testosterone to maintain functional androgen levels, and these changes may directly contribute to tumorigenesis.

Several groups have proposed a selection/adaptation model wherein low androgen levels that persist despite castration provide a selective advantage for the outgrowth of prostate cancer cells that maintain AR signaling through alterations in the androgen/AR signaling axis (Feldman \& Feldman 2001, Balk 2002). A similar hypothesis has been proposed for prostate cancer initiation, in which low levels of androgens create selective pressure for prostate cells that are less dependent upon androgen for growth (Prehn 1999). In support of this hypothesis, it has been shown that during chronic exposure to low testosterone, benign rodent prostate tissue is able to maintain intraprostatic androgens and active AR signaling through mechanisms similar to those that occur in human CRPC, including increased expression of $\mathrm{AR}$ and androgen biosynthesis enzymes (Zhou et al. 2013). In addition, a recent study derived a mathematical model of androgen-regulated prostate growth to study the effects of abnormal androgen levels on selection for pre-malignant phenotypes in early prostate cancer development. The authors found that cell turnover rate increased with decreasing androgen levels, which may increase the rate of mutation and malignant evolution, and that low serum testosterone strongly selects for greater AR expression (Eikenberry et al. 2010). The results of this theoretical study are consistent with the findings of the aforementioned human and animal studies. In sum, it is reasonable to hypothesize that the decline in androgen levels that are a by-product of aging contributes significantly to prostate cancer initiation. There are several possible mechanisms by which this might occur:

\section{Declining testosterone levels trigger the AR 'malignancy switch'}

Analogous to the way in which ADT alters the AR cistrome and transcriptome in metastatic prostate cancer cells, an age-related decrease in serum testosterone could conceivably lead to similar changes in benign prostate cells. Although this hypothesis remains untested, our study has shown that chronic exposure to low testosterone increases the expression of AR and androgen biosynthesis genes in benign rodent prostate cells (Zhou et al. 2013). As discussed above, the overexpression of AR can alter AR-binding sites and transcriptional programs

Published by Bioscientifica Ltd 
(Urbanucci et al. 2012). The increased androgen synthesis induced by chronic low testosterone exposure, coupled with increased AR expression, may also drive chromosomal rearrangements (Weischenfeldt et al. 2013). As discussed previously, these rearrangements can result in androgen-regulated fusion proteins (e.g. TMPRSS2-ERG), which in turn alter the DNA sites at which AR binds. In addition to low testosterone, altering AR expression and the expression of enzymes in the steroid synthesis pathway, the cellular adaptation to low testosterone may involve changes in the expression of AR cofactors, which influence AR occupancy and recruitment of core transcriptional machinery.

While altered expression of AR and AR cofactors could contribute to the AR malignancy switch, so too could the surrounding microenvironment. In the presence of adequate androgens, prostate homeostasis is maintained by the interaction between the stromal and epithelial cells. Binding of androgen to stromal AR causes the secretion of andromedins (Lu et al. 1999, Planz et al. 1999), which promote the proliferation of basal epithelial cells. In turn, AR signaling in luminal epithelial cells inhibits the proliferation of these cells and induces differentiation. In the absence of androgen, as occurs following castration, fibroblasts predominate at the expense of smooth muscle cells in the thickened stroma and stop producing andromedins, fully-differentiated secretory luminal cells undergo apoptosis, and basal cells become quiescent (see reviews Litvinov et al. (2003) and Nelson et al. (2003)). In the presence of low systemic testosterone levels, the cells of the prostate may not respond in the same way as they would in the presence of either normal or castrate testosterone levels. It is possible that in luminal cells, AR binds to and regulates a distinct set of genes following chronic exposure to low testosterone, one that leads to selection of preneoplastic cells that are less dependent on survival and growth signals from the stromal and basal cells. This could initiate the AR malignancy switch that causes AR-driven proliferation of luminal cells.

\section{Declining testosterone levels provide increased opportunity for mutagenesis in prostate stem cells}

The AR malignancy switch must be initiated for cancer to develop, but it must happen in a cell with the underlying potential to become malignant, a cancer initiating cell (CIC). There is ongoing debate concerning the cell of origin for prostate cancer, but most evidence would suggest that it can arise from prostate stem cells or cells with stem-like features. It is very possible that cancers can arise from several different incompletely differentiated cells (Wang et al. 2009b, Goldstein et al. 2010, Taylor et al. 2010, Chen et al. 2013). For the sake of this discussion, these cells will be collectively called stem cells. Because stem cells are few in number in the homeostatic adult prostate, these cells are low probability targets for mutation. However, stem cells are needed to respond to structural damage to prostate lobes and to regenerate atrophied lobes and thus are more prevalent in these settings. Therefore, it is likely that the frequency of cancer would be higher in people with recurrent prostate damage, as this would increase the prevalence of stem cells and the chance for mutagenesis in one of the stem cells. In fact, it has been well documented that men with chronic prostate inflammation, which causes damage that requires prostate lobe regeneration (and the increased presence of stem cells), are at a greater risk for prostate cancer (Haverkamp et al. 2008, Klein \& Silverman 2008, Bardia et al. 2009). Interestingly, we have observed that chronic exposure to low testosterone also leads to prostate damage and the expansion of several putative prostate stem cell populations, including $\mathrm{Lin}-/$ Cd133+/Cd117+ cells and Lin-/Cd49f ${ }^{\text {Hi/Trop } 2+}$ cells (Wang \& Shen (2011) and Y Zhou, M Otto-Duessel, $\mathrm{J}$ Jones, unpublished observations). It is possible that low testosterone, like chronic inflammation, could increase the rate of tumorigenesis by increasing the chance for mutagenesis of a stem cell.

Chronic inflammation not only damages prostate tissue, it also exposes cells to reactive oxygen species, which cause oxidative damage (Xia \& Zweier 1997, Eiserich et al. 1998, De Marzo et al. 1999). Chronic oxidative damage of nucleic acids in prostate cells has been proposed as a major mutagen responsible for both prostate cancer initiation (see review Shen \& Abate-Shen (2010)) and prostate cancer progression (Khandrika et al. 2009). Interestingly, castration is known to cause oxidative stress and damage to prostate tissue (Tam et al. 2003). It is very likely that chronic low testosterone exposure also increases oxidative stress in the prostate gland as men age. In addition, oxidative damage has also been suggested to influence AR signaling by augmenting the expression of $\mathrm{AR}$ and $\mathrm{AR}$ coregulators, or/and by activating intracellular signal-transduction pathways (Shiota et al. 2011). Thus, low testosterone may increase prostate tumorigenesis by i) expanding the population of cells with the potential to become CICs, ii) increasing the risk of mutagenesis in those cells due to increased oxidative stress, and iii) altering AR activity in those stressed cells.

Published by Bioscientifica Ltd. 


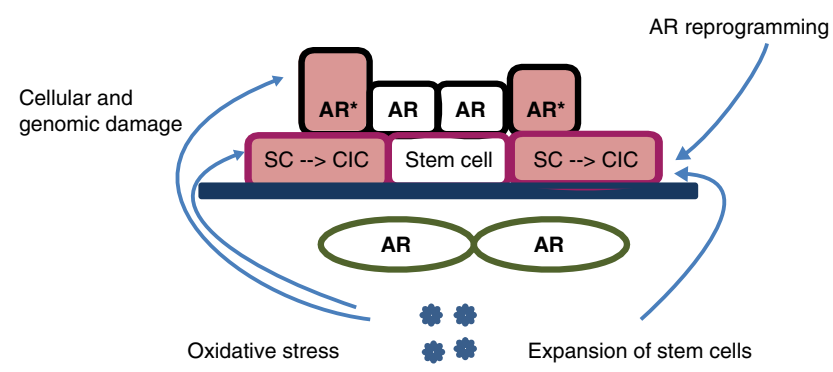

Figure 3

Model of low testosterone contribution to prostate tumorigenesis: low testosterone causes a disruption in the homeostatic balance of the prostate, resulting in an expansion of the prostate stem cell population, which increases the risk of genetic instability in these cells. Oxidative stress, caused in part by low systemic androgen levels, induces DNA damage in these cells, and they become cancer initiating cells (CICs). Low testosterone can also alter the androgen/AR signaling axis in CICs or their progeny, enabling continued AR signaling in the presence of low systemic androgens. A full colour version of this figure is available via http:// dx.doi.org/10.1530/JME-14-0203.

\section{Conclusion}

Numerous studies have defined the importance of the androgen/AR signaling axis in prostate development, homeostasis, and established prostate cancers. Each has provided important mechanistic insight, but we still lack knowledge of the role of androgen/AR signaling in prostate cancer initiation. Many clinical trials and animal studies support the hypothesis that age-related decline in androgen levels is positively associated with initiation of human prostate cancer; however, few studies have focused on deciphering the mechanism(s) that underlie this association. We propose a model (Fig. 3) in which low testosterone: i) selects for adaptive changes in benign prostate tissue that preserves and, possibly, perpetuates AR signaling, ii) expands the population of potential CICs, and iii) contributes to oxidative damage and mutagenesis in those cells. Among the challenges for future studies will be the investigation of the molecular and cellular factors that are altered in response to low testosterone and their contributions to prostate cancer initiation, especially those that induce the AR malignancy switch. Providing molecular evidence for the role of low testosterone in prostate cancer development could have important therapeutic implications. Although there are potential counter-indications (Spitzer et al. 2013), it is possible that TRT or other therapies to maintain testosterone levels in the normal range could be used as a chemo-preventative. However, thorough investigations on the role of androgen/AR signaling in prostate cancer initiation are necessary to provide the foundation for development of effective strategies to prevent or delay the onset of prostate cancer.

Declaration of interest

The authors declare that there is no conflict of interest that could be perceived as prejudicing the impartiality of this review.

\section{Funding}

This review did not receive any specific grant from any funding agency in the public, commercial or not-for-profit sector.

\section{References}

Agoulnik IU, Vaid A, Nakka M, Alvarado M, Bingman WE III, Erdem H, Frolov A, Smith CL, Ayala GE, Ittmann MM et al. 2006 Androgens modulate expression of transcription intermediary factor 2 , an androgen receptor coactivator whose expression level correlates with early biochemical recurrence in prostate cancer. Cancer Research 66 10594-10602. (doi:10.1158/0008-5472.CAN-06-1023)

Andriole G, Bostwick D, Brawley O, Gomella L, Marberger M, Tindall D, Breed S, Somerville M, Rittmaster R \& REDUCE Study Group 2004 Chemoprevention of prostate cancer in men at high risk: rationale and design of the reduction by dutasteride of prostate cancer events (REDUCE) trial. Journal of Urology 172 1314-1317. (doi:10.1097/01.ju. $0000139320.78673 .2 \mathrm{a})$

Baena E, Shao Z, Linn DE, Glass K, Hamblen MJ, Fujiwara Y, Kim J, Nguyen M, Zhang X, Godinho FJ et al. 2013 ETV1 directs androgen metabolism and confers aggressive prostate cancer in targeted mice and patients. Genes and Development 27 683-698. (doi:10.1101/gad.211011.112)

Balk SP 2002 Androgen receptor as a target in androgen-independent prostate cancer. Urology 60 132-138 (discussion 138-139). (doi:10.1016/S0090-4295(02)01593-5)

Banach-Petrosky W, Jessen WJ, Ouyang X, Gao H, Rao J, Quinn J, Aronow BJ \& Abate-Shen C 2007 Prolonged exposure to reduced levels of androgen accelerates prostate cancer progression in Nkx3.1; Pten mutant mice. Cancer Research 67 9089-9096. (doi:10.1158/00085472.CAN-07-2887)

Bardia A, Platz EA, Yegnasubramanian S, De Marzo AM \& Nelson WG 2009 Anti-inflammatory drugs, antioxidants, and prostate cancer prevention. Current Opinion in Pharmacology 9 419-426. (doi:10.1016/ j.coph.2009.06.002)

Bonkhoff H \& Remberger K 1993 Widespread distribution of nuclear androgen receptors in the basal cell layer of the normal and hyperplastic human prostate. Virchows Archiv. A, Pathological Anatomy and Histopathology 422 35-38. (doi:10.1007/BF01605130)

Bosland MC 2000 The role of steroid hormones in prostate carcinogenesis. Journal of the National Cancer Institute. Monographs 27 39-66. (doi:10.1093/oxfordjournals.jncimonographs.a024244)

Bosland MC \& Mahmoud AM 2011 Hormones and prostate carcinogenesis: androgens and estrogens. Journal of Carcinogenesis 10 33. (doi:10.4103/ 1477-3163.90678)

Bubendorf L, Kononen J, Koivisto P, Schraml P, Moch H, Gasser TC, Willi N, Mihatsch MJ, Sauter G \& Kallioniemi OP 1999 Survey of gene amplifications during prostate cancer progression by high-throughput fluorescence in situ hybridization on tissue microarrays. Cancer Research 59 803-806.

Cai C \& Balk SP 2011 Intratumoral androgen biosynthesis in prostate cancer pathogenesis and response to therapy. Endocrine-Related Cancer 18 R175-R182. (doi:10.1530/ERC-10-0339) http://jme.endocrinology-journals.org DOI: 10.1530/JME-14-0203
(C) 2015 Society for Endocrinology Printed in Great Britain 
Carver BS, Tran J, Gopalan A, Chen Z, Shaikh S, Carracedo A, Alimonti A, Nardella C, Varmeh S, Scardino PT et al. 2009 Aberrant ERG expression cooperates with loss of PTEN to promote cancer progression in the prostate. Nature Genetics 41 619-624. (doi:10.1038/ng.370)

Carver BS, Chapinski C, Wongvipat J, Hieronymus H, Chen Y, Chandarlapaty S, Arora VK, Le C, Koutcher J, Scher H et al. 2011 Reciprocal feedback regulation of PI3K and androgen receptor signaling in PTEN-deficient prostate cancer. Cancer Cell 19 575-586. (doi:10.1016/j.ccr.2011.04.008)

Chang BL, Zheng SL, Hawkins GA, Isaacs SD, Wiley KE, Turner A, Carpten JD, Bleecker ER, Walsh PC, Trent JM et al. 2002 Joint effect of HSD3B1 and HSD3B2 genes is associated with hereditary and sporadic prostate cancer susceptibility. Cancer Research 62 1784-1789.

Chen H, Libertini SJ, George M, Dandekar S, Tepper CG, Al-Bataina B, Kung HJ, Ghosh PM \& Mudryj M 2010 Genome-wide analysis of androgen receptor binding and gene regulation in two CWR22derived prostate cancer cell lines. Endocrine-Related Cancer 17 857-873. (doi:10.1677/ERC-10-0081)

Chen S, Gulla S, Cai C \& Balk SP 2012 Androgen receptor serine 81 phosphorylation mediates chromatin binding and transcriptional activation. Journal of Biological Chemistry 287 8571-8583. (doi:10.1074/ jbc.M111.325290)

Chen X, Rycaj K, Liu X \& Tang DG 2013 New insights into prostate cancer stem cells. Cell Cycle 12 579-586. (doi:10.4161/cc.23721)

Choi N, Zhang B, Zhang L, Ittmann M \& Xin L 2012 Adult murine prostate basal and luminal cells are self-sustained lineages that can both serve as targets for prostate cancer initiation. Cancer Cell 21 253-265. (doi:10.1016/j.ccr.2012.01.005)

Coffey K \& Robson CN 2012 Regulation of the androgen receptor by post-translational modifications. Journal of Endocrinology 215 221-237. (doi:10.1530/JOE-12-0238)

Culig Z, Hobisch A, Cronauer MV, Cato AC, Hittmair A, Radmayr C, Eberle J, Bartsch G \& Klocker H 1993 Mutant androgen receptor detected in an advanced-stage prostatic carcinoma is activated by adrenal androgens and progesterone. Molecular Endocrinology 7 1541-1550. (doi:10.1210/ mend.7.12.8145761)

Dehm SM \& Tindall DJ 2011 Alternatively spliced androgen receptor variants. Endocrine-Related Cancer 18 R183-R196. (doi:10.1530/ ERC-11-0141)

De Marzo AM, Marchi VL, Epstein JI \& Nelson WG 1999 Proliferative inflammatory atrophy of the prostate: implications for prostatic carcinogenesis. American Journal of Pathology 155 1985-1992. (doi:10.1016/S0002-9440(10)65517-4)

Demichelis F \& Rubin MA 2007 TMPRSS2-ETS fusion prostate cancer: biological and clinical implications. Journal of Clinical Pathology $\mathbf{6 0}$ 1185-1186. (doi:10.1136/jcp.2007.046557)

Eikenberry SE, Nagy JD \& Kuang Y 2010 The evolutionary impact of androgen levels on prostate cancer in a multi-scale mathematical model. Biology Direct 5 24. (doi:10.1186/1745-6150-5-24)

Eiserich JP, Hristova M, Cross CE, Jones AD, Freeman BA, Halliwell B \& van der Vliet A 1998 Formation of nitric oxide-derived inflammatory oxidants by myeloperoxidase in neutrophils. Nature 391 393-397. (doi:10.1038/34923)

Endogenous Hormones and Prostate Cancer Collaborative Group, Roddam AW, Allen NE, Appleby P \& Key TJ 2008 Endogenous sex hormones and prostate cancer: a collaborative analysis of 18 prospective studies. Journal of the National Cancer Institute $\mathbf{1 0 0}$ 170-183. (doi:10.1093/jnci/djm323)

Feldman BJ \& Feldman D 2001 The development of androgen-independent prostate cancer. Nature Reviews. Cancer 1 34-45. (doi:10.1038/35094009)

Friedlander TW \& Ryan CJ 2012 Targeting the androgen receptor. Urologic Clinics of North America 39 453-464. (doi:10.1016/j.ucl.2012.07.003)

Gao J \& Isaacs JT 1998 Development of an androgen receptor-null model for identifying the initiation site for androgen stimulation of proliferation and suppression of programmed (apoptotic) death of PC-82 human prostate cancer cells. Cancer Research 58 3299-3306.
Gao J, Arnold JT \& Isaacs JT 2001 Conversion from a paracrine to an autocrine mechanism of androgen-stimulated growth during malignant transformation of prostatic epithelial cells. Cancer Research $\mathbf{6 1}$ 5038-5044.

Gao L, Schwartzman J, Gibbs A, Lisac R, Kleinschmidt R, Wilmot B, Bottomly D, Coleman I, Nelson P, McWeeney S et al. 2013 Androgen receptor promotes ligand-independent prostate cancer progression through c-Myc upregulation. PLoS ONE 8 e63563. (doi:10.1371/journal. pone.0063563)

Gioeli D \& Paschal BM 2012 Post-translational modification of the androgen receptor. Molecular and Cellular Endocrinology 352 70-78. (doi:10.1016/j.mce.2011.07.004)

Goldstein AS, Huang J, Guo C, Garraway IP \& Witte ON 2010 Identification of a cell of origin for human prostate cancer. Science 329 568-571. (doi:10.1126/science.1189992)

Goodman PJ, Tangen CM, Crowley JJ, Carlin SM, Ryan A, Coltman CA Jr Ford LG \& Thompson IM 2004 Implementation of the Prostate Cancer Prevention Trial (PCPT). Controlled Clinical Trials 25 203-222. (doi:10.1016/j.cct.2003.11.007)

Haider A, Zitzmann M \& Yassin A 2014 Prostate cancer incidence in hypogonadal men on long-term treatment with testosterone undecanoate injections. ASCO Meeting Abstracts 32 e16041.

Han G, Buchanan G, Ittmann M, Harris JM, Yu X, Demayo FJ, Tilley W \& Greenberg NM 2005 Mutation of the androgen receptor causes oncogenic transformation of the prostate. PNAS 102 1151-1156. (doi:10.1073/pnas.0408925102)

Haverkamp J, Charbonneau B \& Ratliff TL 2008 Prostate inflammation and its potential impact on prostate cancer: a current review. Journal of Cellular Biochemistry 103 1344-1353. (doi:10.1002/jcb.21536)

Hayward SW, Haughney PC, Rosen MA, Greulich KM, Weier HU, Dahiya R \& Cunha GR 1998 Interactions between adult human prostatic epithelium and rat urogenital sinus mesenchyme in a tissue recombination model. Differentiation 63 131-140. (doi:10.1046/j.1432-0436. 1998.6330131.x)

Hu J, Hsu J, Bergerot PG, Yuh BE, Stein CA \& Pal SK 2013 Preoperative therapy for localized prostate cancer: a comprehensive overview. Maturitas 74 3-9. (doi:10.1016/j.maturitas.2012.10.012)

Huggins C \& Clark PJ 1940 Quantitative studies of prostatic secretion: II. The effect of castration and of estrogen injection on the normal and on the hyperplastic prostate glands of dogs. Journal of Experimental Medicine 72 747-762. (doi:10.1084/jem.72.6.747)

Imamoto T, Suzuki H, Fukasawa S, Shimbo M, Inahara M, Komiya A, Ueda T, Shiraishi T \& Ichikawa T 2005 Pretreatment serum testosterone level as a predictive factor of pathological stage in localized prostate cancer patients treated with radical prostatectomy. European Urology 47 308-312. (doi:10.1016/j.eururo.2004.11.003)

Isaacs JT 1984 Antagonistic effect of androgen on prostatic cell death. Prostate 5 545-557. (doi:10.1002/pros.2990050510)

Isom-Batz G, Bianco FJ Jr, Kattan MW, Mulhall JP, Lilja H \& Eastham JA 2005 Testosterone as a predictor of pathological stage in clinically localized prostate cancer. Journal of Urology 173 1935-1937. (doi:10.1097/01.ju.0000158040.33531.e7)

Jang MK, Mochizuki K, Zhou M, Jeong HS, Brady JN \& Ozato K 2005 The bromodomain protein Brd4 is a positive regulatory component of P-TEFb and stimulates RNA polymerase II-dependent transcription. Molecular Cell 19 523-534. (doi:10.1016/j.molcel.2005.06.027)

Jin HJ, Kim J \& Yu J 2013 Androgen receptor genomic regulation. Translational Andrology and Urology 2 158-177. (doi:10.3978/j.issn. 2223-4683.2013.09.01)

Kanda S, Tsuchiya N, Narita S, Inoue T, Huang M, Chiba S, Akihama S, Saito M, Numakura K, Tsuruta $\mathrm{H}$ et al. 2015 Effects of functional genetic polymorphisms in the CYP19A1 gene on prostate cancer risk and survival. International Journal of Cancer 136 74-82. (doi:10.1002/ijc.28952)

Khandrika L, Kumar B, Koul S, Maroni P \& Koul HK 2009 Oxidative stress in prostate cancer. Cancer Letters 282 125-136. (doi:10.1016/j.canlet. 2008.12.011) 
King JC, Xu J, Wongvipat J, Hieronymus H, Carver BS, Leung DH, Taylor BS, Sander C, Cardiff RD, Couto SS et al. 2009 Cooperativity of TMPRSS2-ERG with PI3-kinase pathway activation in prostate oncogenesis. Nature Genetics 41 524-526. (doi:10.1038/ng.371)

Klein EA \& Silverman R 2008 Inflammation, infection, and prostate cancer. Current Opinion in Urology 18 315-319. (doi:10.1097/MOU. 0b013e3282f9b3b7)

Klezovitch O, Risk M, Coleman I, Lucas JM, Null M, True LD, Nelson PS \& Vasioukhin V 2008 A causal role for ERG in neoplastic transformation of prostate epithelium. PNAS 105 2105-2110. (doi:10.1073/pnas. 0711711105)

Kraft P, Pharoah P, Chanock SJ, Albanes D, Kolonel LN, Hayes RB, Altshuler D, Andriole G, Berg C, Boeing H et al. 2005 Genetic variation in the HSD17B1 gene and risk of prostate cancer. PLoS Genetics 1 e68. (doi:10.1371/journal.pgen.0010068)

Kumar-Sinha C, Tomlins SA \& Chinnaiyan AM 2008 Recurrent gene fusions in prostate cancer. Nature Reviews. Cancer 8 497-511. (doi:10.1038/nrc2402)

Kurita T, Wang YZ, Donjacour AA, Zhao C, Lydon JP, O'Malley BW, Isaacs JT, Dahiya R \& Cunha GR 2001 Paracrine regulation of apoptosis by steroid hormones in the male and female reproductive system. Cell Death and Differentiation 8 192-200. (doi:10.1038/sj.cdd.4400797)

Kyprianou N \& Isaacs JT 1988 Activation of programmed cell death in the rat ventral prostate after castration. Endocrinology 122 552-562. (doi:10.1210/endo-122-2-552)

Lamont KR \& Tindall DJ 2011 Minireview: Alternative activation pathways for the androgen receptor in prostate cancer. Molecular Endocrinology 25 897-907. (doi:10.1210/me.2010-0469)

Latil AG, Azzouzi R, Cancel GS, Guillaume EC, Cochan-Priollet B, Berthon PL \& Cussenot O 2001 Prostate carcinoma risk and allelic variants of genes involved in androgen biosynthesis and metabolism pathways. Cancer 92 1130-1137. (doi:10.1002/1097-0142(20010901)92:5 < 1130::AID-CNCR1430>3.0.CO;2-B)

Lee SO, Tian J, Huang CK, Ma Z, Lai KP, Hsiao H, Jiang M, Yeh S \& Chang C 2012 Suppressor role of androgen receptor in proliferation of prostate basal epithelial and progenitor cells. Journal of Endocrinology $\mathbf{2 1 3}$ 173-182. (doi:10.1530/JOE-11-0474)

Leibowitz RL \& Tucker SJ 2001 Treatment of localized prostate cancer with intermittent triple androgen blockade: preliminary results in 110 consecutive patients. Oncologist 6 177-182. (doi:10.1634/ theoncologist.6-2-177)

Li LC, Okino ST \& Dahiya R 2004 DNA methylation in prostate cancer. Biochimica et Biophysica Acta 1704 87-102. (doi:10.1016/j.bbcan.2004. 06.001)

Li Y, Hwang TH, Oseth LA, Hauge A, Vessella RL, Schmechel SC, Hirsch B, Beckman KB, Silverstein KA \& Dehm SM 2012 AR intragenic deletions linked to androgen receptor splice variant expression and activity in models of prostate cancer progression. Oncogene 31 4759-4767. (doi:10.1038/onc.2011.637)

Lindstrom S, Ma J, Altshuler D, Giovannucci E, Riboli E, Albanes D, Allen NE, Berndt SI, Boeing H, Bueno-de-Mesquita HB et al. 2010 A large study of androgen receptor germline variants and their relation to sex hormone levels and prostate cancer risk. Results from the National Cancer Institute Breast and Prostate Cancer Cohort Consortium. Journal of Clinical Endocrinology and Metabolism 95 E121-E127. (doi:10.1210/jc.2009-1911)

Litvinov IV, De Marzo AM \& Isaacs JT 2003 Is the Achilles' heel for prostate cancer therapy a gain of function in androgen receptor signaling? Journal of Clinical Endocrinology and Metabolism 88 2972-2982. (doi:10.1210/jc.2002-022038)

Lu W, Luo Y, Kan M \& McKeehan WL 1999 Fibroblast growth factor-10. A second candidate stromal to epithelial cell andromedin in prostate. Journal of Biological Chemistry 274 12827-12834. (doi:10.1074/jbc.274. 18.12827)

Marker PC, Donjacour AA, Dahiya R \& Cunha GR 2003 Hormonal, cellular, and molecular control of prostatic development. Developmental Biology 253 165-174. (doi:10.1016/S0012-1606(02)00031-3)
Massengill JC, Sun L, Moul JW, Wu H, McLeod DG, Amling C, Lance R, Foley J, Sexton W, Kusuda L et al. 2003 Pretreatment total testosterone level predicts pathological stage in patients with localized prostate cancer treated with radical prostatectomy. Journal of Urology 169 1670-1675. (doi:10.1097/01.ju.0000062674.43964.d0)

Massie CE, Lynch A, Ramos-Montoya A, Boren J, Stark R, Fazli L, Warren A, Scott H, Madhu B, Sharma N et al. 2011 The androgen receptor fuels prostate cancer by regulating central metabolism and biosynthesis. EMBO Journal 30 2719-2733. (doi:10.1038/emboj.2011.158)

McLeod DG, Iversen P, See WA, Morris T, Armstrong J, Wirth MP \& Casodex Early Prostate Cancer Trialists' Group 2006 Bicalutamide $150 \mathrm{mg}$ plus standard care vs standard care alone for early prostate cancer. BJU International 97 247-254. (doi:10.1111/j.1464-410X.2005. 06051.x)

Memarzadeh S, Cai H, Janzen DM, Xin L, Lukacs R, Riedinger M, Zong Y, DeGendt K, Verhoeven G, Huang J et al. 2011 Role of autonomous androgen receptor signaling in prostate cancer initiation is dichotomous and depends on the oncogenic signal. PNAS 108 7962-7967. (doi:10.1073/pnas.1105243108)

Mills IG 2014 Maintaining and reprogramming genomic androgen receptor activity in prostate cancer. Nature Reviews. Cancer 14 187-198. (doi:10.1038/nrc3678)

Mirosevich J, Bentel JM, Zeps N, Redmond SL, D'Antuono MF \& Dawkins HJ 1999 Androgen receptor expression of proliferating basal and luminal cells in adult murine ventral prostate. Journal of Endocrinology 162 341-350. (doi:10.1677/joe.0.1620341)

Morgentaler A, Bruning CO III \& DeWolf WC 1996 Occult prostate cancer in men with low serum testosterone levels. Journal of the American Medical Association 276 1904-1906. (doi:10.1001/jama.1996. 03540230054035)

Mostaghel EA \& Plymate S 2011 New hormonal therapies for castrationresistant prostate cancer. Endocrinology and Metabolism Clinics of North America 40 625-642. (doi:10.1016/j.ecl.2011.05.013)

Mostaghel EA, Lin DW, Amory JK, Wright JL, Marck BT, Nelson PS, Matsumoto AM, Bremner WJ \& Page ST 2012 Impact of male hormonal contraception on prostate androgens and androgen action in healthy men: a randomized, controlled trial. Journal of Clinical Endocrinology and Metabolism 97 2809-2817. (doi:10.1210/jc.2012-1536)

Mulholland DJ, Dedhar S, Wu H \& Nelson CC 2006 PTEN and GSK3 $\beta$ : key regulators of progression to androgen-independent prostate cancer. Oncogene 25 329-337. (doi:10.1038/sj.onc.1209020)

Mulholland DJ, Tran LM, Li Y, Cai H, Morim A, Wang S, Plaisier S, Garraway IP, Huang J, Graeber TG et al. 2011 Cell autonomous role of PTEN in regulating castration-resistant prostate cancer growth. Cancer Cell 19 792-804. (doi:10.1016/j.ccr.2011.05.006)

Nelson PS, Clegg N, Arnold H, Ferguson C, Bonham M, White J, Hood L \& Lin B 2002 The program of androgen-responsive genes in neoplastic prostate epithelium. PNAS 99 11890-11895. (doi:10.1073/pnas. 182376299)

Nelson WG, De Marzo AM \& Isaacs WB 2003 Prostate cancer. New England Journal of Medicine 349 366-381. (doi:10.1056/NEJMra021562)

Page ST, Lin DW, Mostaghel EA, Hess DL, True LD, Amory JK, Nelson PS, Matsumoto AM \& Bremner WJ 2006 Persistent intraprostatic androgen concentrations after medical castration in healthy men. Journal of Clinical Endocrinology and Metabolism 91 3850-3856. (doi:10.1210/ jc.2006-0968)

Planz B, Aretz HT, Wang Q, Tabatabaei S, Kirley SD, Lin CW \& McDougal WS 1999 Immunolocalization of the keratinocyte growth factor in benign and neoplastic human prostate and its relation to androgen receptor. Prostate 41 233-242. (doi:10.1002/(SICI)1097-0045(19991201)41: $4<233:: A I D-P R O S 3>3.0 . C O ; 2-L)$

Pointis G, Latreille MT, Mignot TM, Janssens Y \& Cedard L 1979 Regulation of testosterone synthesis in the fetal mouse testis. Journal of Steroid Biochemistry 11 1609-1612. (doi:10.1016/0022-4731(79)90357-1) 
Pointis G, Latreille MT \& Cedard L 1980 Gonado-pituitary relationships in the fetal mouse at various times during sexual differentiation. Journal of Endocrinology 86 483-488. (doi:10.1677/joe.0.0860483)

Pomerantz MM, Li F, Chonkar A, Vazquez F, Chabot M, Cejas P, Bowden M, Shivdasani R, Hahn WC, Brown M et al. 2014 Effect of HOXB13 and FOXA1 on the AR cistrome during prostate tumorigenesis in primary human tissue. Journal of Clinical Oncology 32 (suppl) abstr 5018.

Prehn RT 1999 On the prevention and therapy of prostate cancer by androgen administration. Cancer Research 59 4161-4164.

Price DK, Chau CH, Till C, Goodman PJ, Baum CE, Ockers SB, English BC, Minasian L, Parnes HL, Hsing AW et al. 2010 Androgen receptor CAG repeat length and association with prostate cancer risk: results from the prostate cancer prevention trial. Journal of Urology 184 2297-2302. (doi:10.1016/j.juro.2010.08.005)

Pritchard C, Mecham B, Dumpit R, Coleman I, Bhattacharjee M, Chen Q, Sikes RA \& Nelson PS 2009 Conserved gene expression programs integrate mammalian prostate development and tumorigenesis. Cancer Research 69 1739-1747. (doi:10.1158/0008-5472.CAN-07-6817)

Ribeiro FR, Henrique R, Martins AT, Jeronimo C \& Teixeira MR 2007 Relative copy number gain of MYC in diagnostic needle biopsies is an independent prognostic factor for prostate cancer patients. European Urology 52 116-125. (doi:10.1016/j.eururo.2006.09.018)

Sauvageau M \& Sauvageau G 2010 Polycomb group proteins: multi-faceted regulators of somatic stem cells and cancer. Cell Stem Cell 7 299-313. (doi:10.1016/j.stem.2010.08.002)

Schaeffer EM, Marchionni L, Huang Z, Simons B, Blackman A, Yu W, Parmigiani G \& Berman DM 2008 Androgen-induced programs for prostate epithelial growth and invasion arise in embryogenesis and are reactivated in cancer. Oncogene 27 7180-7191. (doi:10.1038/onc. 2008.327)

Schatzl G, Madersbacher S, Thurridl T, Waldmuller J, Kramer G, Haitel A \& Marberger M 2001 High-grade prostate cancer is associated with low serum testosterone levels. Prostate 47 52-58. (doi:10.1002/pros.1046)

Scholz MC, Lam RY, Strum SB, Labarba DJ, Becker LK, Chang P, Farhoumand N \& Jennrich RI 2011 Primary intermittent androgen deprivation as initial therapy for men with newly diagnosed prostate cancer. Clinical Genitourinary Cancer 9 89-94. (doi:10.1016/j.clgc.2011. 07.002)

Setiawan VW, Schumacher FR, Haiman CA, Stram DO, Albanes D, Altshuler D, Berglund G, Buring J, Calle EE, Clavel-Chapelon F et al. 2007 CYP17 genetic variation and risk of breast and prostate cancer from the National Cancer Institute Breast and Prostate Cancer Cohort Consortium (BPC3). Cancer Epidemiology, Biomarkers \& Prevention 16 2237-2246. (doi:10.1158/1055-9965.EPI-07-0589)

Sharma NL, Massie CE, Ramos-Montoya A, Zecchini V, Scott HE, Lamb AD, MacArthur S, Stark R, Warren AY, Mills IG et al. 2013 The androgen receptor induces a distinct transcriptional program in castrationresistant prostate cancer in man. Cancer Cell 23 35-47. (doi:10.1016/ j.ccr.2012.11.010)

Shen MM \& Abate-Shen C 2010 Molecular genetics of prostate cancer: new prospects for old challenges. Genes and Development 24 1967-2000. (doi:10.1101/gad.1965810)

Shin S, Kim TD, Jin F, van Deursen JM, Dehm SM, Tindall DJ, Grande JP, Munz JM, Vasmatzis G \& Janknecht R 2009 Induction of prostatic intraepithelial neoplasia and modulation of androgen receptor by ETS variant 1/ETS-related protein 81. Cancer Research $698102-8110$. (doi:10.1158/0008-5472.CAN-09-0941)

Shiota M, Yokomizo A, Fujimoto N \& Naito S 2011 Androgen receptor cofactors in prostate cancer: potential therapeutic targets of castrationresistant prostate cancer. Current Cancer Drug Targets 11 870-881. (doi:10.2174/156800911796798904)

Siegel R, Naishadham D \& Jemal A 2013 Cancer statistics, 2013. CA: A Cancer Journal for Clinicians 63 11-30. (doi:10.3322/caac.21166) Spitzer M, Huang G, Basaria S, Travison TG \& Bhasin S 2013 Risks and benefits of testosterone therapy in older men. Nature Reviews. Endocrinology 9 414-424. (doi:10.1038/nrendo.2013.73)
Stanbrough M, Leav I, Kwan PW, Bubley GJ \& Balk SP 2001 Prostatic intraepithelial neoplasia in mice expressing an androgen receptor transgene in prostate epithelium. PNAS 98 10823-10828. (doi:10.1073/ pnas.191235898)

Stattin P, Lumme S, Tenkanen L, Alfthan H, Jellum E, Hallmans G, Thoresen S, Hakulinen T, Luostarinen T, Lehtinen M et al. 2004 High levels of circulating testosterone are not associated with increased prostate cancer risk: a pooled prospective study. International Journal of Cancer 108 418-424. (doi:10.1002/ijc.11572)

Sugimura Y, Cunha GR \& Donjacour AA 1986 Morphological and histological study of castration-induced degeneration and androgeninduced regeneration in the mouse prostate. Biology of Reproduction 34 973-983. (doi:10.1095/biolreprod34.5.973)

Suzuki K, Nakazato H, Matsui H, Koike H, Okugi H, Ohtake N, Takei T, Nakata S, Hasumi M \& Yamanaka H 2003 Association of the genetic polymorphism of the CYP19 intron 4[TTTA]n repeat with familial prostate cancer risk in a Japanese population. Anticancer Research 23 4941-4946.

Tam NN, Gao Y, Leung YK \& Ho SM 2003 Androgenic regulation of oxidative stress in the rat prostate: involvement of $\mathrm{NAD}(\mathrm{P}) \mathrm{H}$ oxidases and antioxidant defense machinery during prostatic involution and regrowth. American Journal of Pathology 163 2513-2522. (doi:10.1016/ S0002-9440(10)63606-1)

Taplin ME, Bubley GJ, Shuster TD, Frantz ME, Spooner AE, Ogata GK, Keer HN \& Balk SP 1995 Mutation of the androgen-receptor gene in metastatic androgen-independent prostate cancer. New England Journal of Medicine 332 1393-1398. (doi:10.1056/ NEJM199505253322101)

Taplin ME, Bubley GJ, Ko YJ, Small EJ, Upton M, Rajeshkumar B \& Balk SP 1999 Selection for androgen receptor mutations in prostate cancers treated with androgen antagonist. Cancer Research 59 2511-2515.

Taplin ME, Rajeshkumar B, Halabi S, Werner CP, Woda BA, Picus J, Stadler W, Hayes DF, Kantoff PW, Vogelzang NJ et al. 2003 Androgen receptor mutations in androgen-independent prostate cancer: Cancer and Leukemia Group B Study 9663. Journal of Clinical Oncology 21 2673-2678. (doi:10.1200/JCO.2003.11.102)

Taylor RA, Toivanen R \& Risbridger GP 2010 Stem cells in prostate cancer: treating the root of the problem. Endocrine-Related Cancer $\mathbf{1 7}$ R273-R285. (doi:10.1677/ERC-10-0145)

Thompson VC, Day TK, Bianco-Miotto T, Selth LA, Han G, Thomas M, Buchanan G, Scher HI, Nelson CC, Australian Prostate Cancer BioResource et al. 2012 A gene signature identified using a mouse model of androgen receptor-dependent prostate cancer predicts biochemical relapse in human disease. International Journal of Cancer 131 662-672. (doi:10.1002/ijc.26414)

Tomlins SA, Mehra R, Rhodes DR, Cao X, Wang L, Dhanasekaran SM, Kalyana-Sundaram S, Wei JT, Rubin MA, Pienta KJ et al. 2007a Integrative molecular concept modeling of prostate cancer progression. Nature Genetics 39 41-51. (doi:10.1038/ng1935)

Tomlins SA, Laxman B, Dhanasekaran SM, Helgeson BE, Cao X, Morris DS, Menon A, Jing X, Cao Q, Han B et al. 2007b Distinct classes of chromosomal rearrangements create oncogenic ETS gene fusions in prostate cancer. Nature 448 595-599. (doi:10.1038/nature06024)

Tsuchiya N, Wang L, Suzuki H, Segawa T, Fukuda H, Narita S, Shimbo M, Kamoto T, Mitsumori K, Ichikawa T et al. 2006 Impact of IGF-I and CYP19 gene polymorphisms on the survival of patients with metastatic prostate cancer. Journal of Clinical Oncology 24 1982-1989. (doi:10.1200/JCO.2005.02.9439)

Ueda T, Mawji NR, Bruchovsky N \& Sadar MD 2002 Ligand-independent activation of the androgen receptor by interleukin- 6 and the role of steroid receptor coactivator-1 in prostate cancer cells. Journal of Biological Chemistry 277 38087-38094. (doi:10.1074/jbc.M203313200)

Urbanucci A, Sahu B, Seppala J, Larjo A, Latonen LM, Waltering KK, Tammela TL, Vessella RL, Lahdesmaki H, Janne OA et al. 2012 Overexpression of androgen receptor enhances the binding of the 
receptor to the chromatin in prostate cancer. Oncogene 31 2153-2163. (doi:10.1038/onc.2011.401)

Velasco AM, Gillis KA, Li Y, Brown EL, Sadler TM, Achilleos M, Greenberger LM, Frost P, Bai W \& Zhang Y 2004 Identification and validation of novel androgen-regulated genes in prostate cancer. Endocrinology 145 3913-3924. (doi:10.1210/en.2004-0311)

Wang ZA \& Shen MM 2011 Revisiting the concept of cancer stem cells in prostate cancer. Oncogene 30 1261-1271. (doi:10.1038/onc. 2010.530)

Wang Y, Hayward S, Cao M, Thayer K \& Cunha G 2001 Cell differentiation lineage in the prostate. Differentiation 68 270-279. (doi:10.1046/j.14320436.2001.680414.x)

Wang XD, Wang BE, Soriano R, Zha J, Zhang Z, Modrusan Z, Cunha GR \& Gao WQ 2007 Expression profiling of the mouse prostate after castration and hormone replacement: implication of H-cadherin in prostate tumorigenesis. Differentiation 75 219-234. (doi:10.1111/ j.1432-0436.2006.00135.x)

Wang Q, Li W, Zhang Y, Yuan X, Xu K, Yu J, Chen Z, Beroukhim R, Wang H, Lupien $\mathrm{M}$ et al. 2009a Androgen receptor regulates a distinct transcription program in androgen-independent prostate cancer. Cell 138 245-256. (doi:10.1016/j.cell.2009.04.056)

Wang X, Kruithof-de Julio M, Economides KD, Walker D, Yu H, Halili MV, Hu YP, Price SM, Abate-Shen C \& Shen MM 2009b A luminal epithelial stem cell that is a cell of origin for prostate cancer. Nature $\mathbf{4 6 1} 495-500$. (doi:10.1038/nature08361)

Weischenfeldt J, Simon R, Feuerbach L, Schlangen K, Weichenhan D, Minner S, Wuttig D, Warnatz HJ, Stehr H, Rausch T et al. 2013 Integrative genomic analyses reveal an androgen-driven somatic alteration landscape in early-onset prostate cancer. Cancer Cell $\mathbf{2 3}$ 159-170. (doi:10.1016/j.ccr.2013.01.002)

Wikstrom P, Westin P, Stattin P, Damber JE \& Bergh A 1999 Early castration-induced upregulation of transforming growth factor $\beta 1$ and its receptors is associated with tumor cell apoptosis and a major decline in serum prostate-specific antigen in prostate cancer patients. Prostate 38 268-277. (doi:10.1002/(SICI)1097-0045(19990301)38:4<268::AIDPROS2 > 3.0.CO;2-4)

Williams JL, Yoishimoto M, Boag AH, Squire JA \& Park PC 2010 TMPRSS2:ETS gene fusions in prostate cancer. Atlas of Genetics and Cytogenetics in Oncology and Haematology 15 699-716.

Wirth M, Tyrrell C, Delaere K, Sanchez-Chapado M, Ramon J, Wallace DM, Hetherington J, Pina F, Heyns CF, Navani S et al. 2007 Bicalutamide (Casodex) $150 \mathrm{mg}$ plus standard care in early non-metastatic prostate cancer: results from Early Prostate Cancer Trial 24 at a median 7 years' follow-up. Prostate Cancer and Prostatic Diseases 10 87-93. (doi:10.1038/ sj.pcan.4500916)

Wu CT, Altuwaijri S, Ricke WA, Huang SP, Yeh S, Zhang C, Niu Y, Tsai MY \& Chang C 2007 Increased prostate cell proliferation and loss of cell differentiation in mice lacking prostate epithelial androgen receptor. PNAS 104 12679-12684. (doi:10.1073/pnas.0704940104)
Xia Y \& Zweier JL 1997 Superoxide and peroxynitrite generation from inducible nitric oxide synthase in macrophages. PNAS 94 6954-6958. (doi:10.1073/pnas.94.13.6954)

Xu J, Zheng SL, Chang B, Smith JR, Carpten JD, Stine OC, Isaacs SD, Wiley KE, Henning L, Ewing C et al. 2001 Linkage of prostate cancer susceptibility loci to chromosome 1. Human Genetics 108 335-345. (doi:10.1007/s004390100488)

$\mathrm{Xu}$ J, Wu RC \& O'Malley BW 2009 Normal and cancer-related functions of the p160 steroid receptor co-activator (SRC) family. Nature Reviews. Cancer 9 615-630. (doi:10.1038/nrc2695)

$\mathrm{Xu} \mathrm{K,} \mathrm{Wu} \mathrm{ZJ,} \mathrm{Groner} \mathrm{AC,} \mathrm{He} \mathrm{HH,} \mathrm{Cai} \mathrm{C,} \mathrm{Lis} \mathrm{RT,} \mathrm{Wu} \mathrm{X,} \mathrm{Stack} \mathrm{EC,} \mathrm{Loda} \mathrm{M,}$ Liu T et al. 2012 EZH2 oncogenic activity in castration-resistant prostate cancer cells is Polycomb-independent. Science 338 1465-1469. (doi:10.1126/science.1227604)

Yang YA \& Yu J 2013 EZH2, an epigenetic driver of prostate cancer. Protein \& Cell 4 331-341. (doi:10.1007/s13238-013-2093-2)

Yang M, Xie W, Mostaghel E, Nakabayashi M, Werner L, Sun T, Pomerantz M, Freedman M, Ross R, Regan M et al. 2011 SLCO2B1 and SLCO1B3 may determine time to progression for patients receiving androgen deprivation therapy for prostate cancer. Journal of Clinical Oncology 29 2565-2573. (doi:10.1200/JCO.2010.31.2405)

Yassin D-J, Manka L, Yassin A \& Hammerer P 2014 Effect of testosterone treatment in hypogonadal men on prostate cancer risk: results of a prospective comparative study -8 years follow-up analysis to age-matched controls. ASCO Meeting Abstracts 32 e16051.

Yegnasubramanian S, Kowalski J, Gonzalgo ML, Zahurak M, Piantadosi S, Walsh PC, Bova GS, De Marzo AM, Isaacs WB \& Nelson WG 2004 Hypermethylation of $\mathrm{CpG}$ islands in primary and metastatic human prostate cancer. Cancer Research 64 1975-1986. (doi:10.1158/00085472.CAN-03-3972)

Yu J, Yu J, Mani RS, Cao Q, Brenner CJ, Cao X, Wang X, Wu L, Li J, Hu M et al. 2010 An integrated network of androgen receptor, polycomb, and TMPRSS2-ERG gene fusions in prostate cancer progression. Cancer Cell 17 443-454. (doi:10.1016/j.ccr.2010.03.018)

Yu S, Yeh CR, Niu Y, Chang HC, Tsai YC, Moses HL, Shyr CR, Chang C \& Yeh S 2012 Altered prostate epithelial development in mice lacking the androgen receptor in stromal fibroblasts. Prostate 72 437-449. (doi:10.1002/pros.21445)

Zhao XY, Malloy PJ, Krishnan AV, Swami S, Navone NM, Peehl DM \& Feldman D 2000 Glucocorticoids can promote androgen-independent growth of prostate cancer cells through a mutated androgen receptor. Nature Medicine 6 703-706. (doi:10.1038/76287)

Zhao JC, Yu J, Runkle C, Wu L, Hu M, Wu D, Liu JS, Wang Q, Qin ZS \& Yu J 2012 Cooperation between Polycomb and androgen receptor during oncogenic transformation. Genome Research 22 322-331. (doi:10.1101/ gr.131508.111)

Zhou Y, Otto-Duessel M, He M, Markel S, Synold T \& Jones JO 2013 Low systemic testosterone levels induce androgen maintenance in benign rat prostate tissue. Journal of Molecular Endocrinology 51 143-153. (doi:10.1530/JME-13-0060)

Received in final form 20 October 2014

Accepted 28 October 2014

Accepted Preprint published online 28 October 2014 http://jme.endocrinology-journals.org

DOI: $10.1530 / J M E-14-0203$
(C) 2015 Society for Endocrinology Printed in Great Britain
Published by Bioscientifica Ltd. 